\title{
The Effect of Kuchala (Arum Korolkowii Regel, 1873) Tuber Tincture to Increase of the Serum Testosterone in the Adult Male Guinea Pigs (Cavia Porcellus Linnaeus, 1758)
}

\author{
NURBEK SAIDILLAEVICH ALDAYROV ( $\nabla$ nurbek.aldayarov@manas.edu.kg ) \\ Kyrgyz-Turkish Manas University https://orcid.org/0000-0001-8693-5904 \\ JARKINAY JUMABEKOVA \\ Kyrgyz-Turkish Manas University \\ GULBUBU KURMANBEKOVA \\ Kyrgyz-Turkish Manas University \\ NURJAMAL OMURZAKOVA \\ Kyrgyz-Turkish Manas University \\ BERMET KIDIRALIEVA \\ Kyrgyz-Turkish Manas University \\ BAKIT BORKOEV \\ Kyrgyz-Turkish Manas University \\ KALIPA SALIEVA \\ Kyrgyz-Turkish Manas University \\ ASKARBEK TULOBAEV \\ Kyrgyz-Turkish Manas University \\ RUSLAN SALYKOV \\ Kyrgyz-Turkish Manas University \\ GULNARA SHARSHENALIEVA \\ Kyrgyz-Turkish Manas University \\ KADYRBAY CHEKIROV \\ Kyrgyz-Turkish Manas University
}

\section{Research}

Keywords: Kuchala tuber tincture, Hematology, Serum biochemistry, Histology, Testosterone, Adult male guinea pigs

Posted Date: December 15th, 2020

DOI: https://doi.org/10.21203/rs.3.rs-125964/v1

License: (c) (1) This work is licensed under a Creative Commons Attribution 4.0 International License. Read Full License 


\section{Abstract}

Background

Kuchala (Arum korolkowii Regel) is one of the medicinal plants often used in folk medicine in the Kyrgyz Republic. As a medicinal raw material, tubers tincture used in small doses to increase human sexual potency. However, there is no scientific evidence proving the medicinal effects of kuchala. For these reasons, we decided to study the effect of kuchala tuber tincture on the sexual potency of adult male guinea pigs.

Methods

We analyzed the effect of kuchala at age \pm 48 -month-old, in 12 male guinea pigs. Prepared $10 \%$ tuber tincture of kuchala in $70 \%$ ethanol was administered perorally a once-daily dose of $150 \mu \mathrm{l}$ for 30 days for the male guinea pigs. These study data were obtained by the ethological, hematological and serum biochemistry, gross anatomical, histological and statistical methods.

Results

The hematological and serum biochemistry parameters were significantly different between control and experimental group. Neutrophils' percentage in experimental group was significantly lower ( $\left.{ }^{d} P<0.001\right)$ than in control group. Lymphocyte counts on the contrary were significantly higher in experimental group $\left({ }^{d} \mathrm{P}<0.001\right)$. RBC counts, $\mathrm{Hgb}, \mathrm{Hct}, \mathrm{MCH}$ and $\mathrm{MCHC}$ were significantly higher in the experimental group $\left({ }^{d} \mathrm{P}<0.001 ;{ }^{d} \mathrm{P}<0.001 ;{ }^{C} \mathrm{P}<\right.$ $0.01 ;{ }^{d} \mathrm{P}<0.001 ;{ }^{d} \mathrm{P}<0.001$ respectively) than control group. The color indicator and mean platelet volume contrary was higher $\left({ }^{\mathrm{b}} \mathrm{P}<0.05\right)$ and significantly higher $\left({ }^{\mathrm{d}} \mathrm{P}<0.001\right)$ in control animals than in the experimental. ALT and AST levels were lower in experimental than control group (both $\left.{ }^{\mathrm{d}} \mathrm{P}<0,001\right)$. The testosterone concentration in serum was much higher $\left({ }^{\mathrm{d} P}<0,001\right)$ in the experimental group. Microscopically was found minor structural damage in the liver tissue that indicates a metabolic disorder. However, the testes showed an improvement in spermatogenesis in the experimental if compared with the control group.

Conclusion

The $10 \%$ kuchala tuber tincture in $70 \%$ ethanol has a positive effect to improve the sexual potency of old guinea pigs by increasing the production of testosterone and increasing spermatogenesis.

\section{Background}

Since ancient times, people have successfully used folk medicine, which containing inexhaustible information about medicinal plants as an important therapeutic agent in both human and veterinary medicine $[1,2,3,4,5]$. Many of the treatment methods have been passed down through families for generations, and some of these have been adapted for use by the modern medical practice. Among others, the Kyrgyz folk medicine has occupied an important place in the nomadic civilization of the Kyrgyz people.

The Kyrgyz Republic is a mountainous country in central Asia. Due to their extreme environment and climate, there are diverse ranges of species of plants, including more than 200 species of medical plants. Many of the medical plants used in Kyrgyz folk medicine have not been studied using modern scientific techniques [6]. Arum korolkowii Regel is one of the medicinal plants often used in the folk medicine of Central Asia, which has not lost its relevance even nowadays. The vernacular name of this medicinal plant is kuchala. A. korolkowii R., 1873 belongs to the genus 
Arum L. of the family Araceae Juss. and grows in soil pockets of rocky hillsides, beneath low scrub. Its native range is Central Asia, North-Western China, Northern Iran and Afghanistan. A. korolkowii R. is perennial tuberous herb sprouting in early spring from a discoid, vertically orientated tuber. It has a well-described biological characteristic $[7,8]$. However, there is another plant also called kuchla or Chinese kuchla (Strychnos nux-vomica). S. nux-vomica is an evergreen tree up to $25 \mathrm{~m}$ height. Its dried seeds (Nux vomica) used in modern and tradition medicine $[9,10]$.

A. korolkowii R. is very poisonous herb and in folk medicine as a medicinal raw material was used a tincture of tubers in small doses for increasing human potency and immunity, to treat infertility and stomach ulcers, diseases of nasopharynx and respiratory tract, and also eliminates fatigue and gives strength. The powdered tuber is used to treat poisonous snake and scorpion bites, fungal skin diseases and hemorrhoids [7]. The medicinal properties of

kuchala were mentioned in the works of Avicenna and in the Kyrgyz folk epics as «Manas» [11] and «Semetey» [12]. According to the mentioned sources, the milky and sour-milky (kumys) tinctures of the tubers of this plant often used among the elderly (over 70 years) as a drug that increases the sexual potency of men. However, there are no modern scientific data proving the medicinal properties of kuchala, especially, its effect on human potency. Besides, the $A$. korolkowii R. chemical composition has not been studied yet. In this regard, we decided to experiment with kuchala tuber tinctures on laboratory animals, with particular interest on adult male guinea pigs.

Many characteristics make the guinea pig an art model for biomedical research [13]. Guinea pig was comprehensive studied as laboratory animal in biological, morphological and physiological approaches. Its size and lifestyle make the guinea pig easy to keep and conducts experimental study, and importantly, it has many same morphological and physiological characteristics with human $[13,14]$, including in reproduction $[15,16,17,18,19,20]$.

Consequently, guinea pigs often used in a number of infectious bacterial and noninfectious diseases as a biological model $[14,21]$.

Blood evaluations are a prime diagnostic way in both human and animal medicine. Because hematological and serum biochemistry data can show changes in physiological disturbances such as systemic inflammation, renal or hepatocellular disorders [13]. The aim of the present study was to investigate the effect of kuchala (Arum korolkowii Regel) tuber tincture on the hematological and serum biochemistry parameters, and the testis and liver structures of the adult male guinea pigs (Cavia porcellus Linnaeus, 1758).

\section{Materials And Methods}

\section{Kuchala tubers and making the tincture}

Dried kuchala tubers, in the amount of 5 pieces (total $49.62 \mathrm{~g}$ ), were purchased at local markets in Bishkek (Kyrgyz Republic). Each of the tuber pieces was cleaned with warm water and then $70 \%$ of ethanol and dried on air at room temperature. Tubers with peel were shredded using a manual grinder. The grind tuber was weighed on an electronic weight Precisa (Switzerland) and prepared 10\% tincture in $70 \%$ ethanol. The tincture poured in the dark glass bottle closed with a tight cover and it was placed in a dark place at room temperature. Two times per day, the tincture was mixed, and this process was continued for 14 days until the tincture was ready. On the 15th day, the tincture was filtered through dense gauze and then was filtered through filter paper. Prepared $10 \%$ tincture in $70 \%$ ethanol was stored in the refrigerator $\left(+4^{\circ} \mathrm{C}\right)$ and was used for the experimental study. The main phases of the experimental study, in sequential order, shown on the following schematic image (Fig. 1).

\section{Treatments and handling}


We observed the behavior of guinea pigs during the adaptation period (10 days) and by their physical activity and body weight, the experimental animals were divided in two groups. Both the control and experimental groups of animals were formed according to the above-mentioned principle. The control group was created of 10 and the experimental group of 12 male animals and both groups were kept in the same conditions. Every day from 8:00 to 9:00 a.m. to experimental animals were administered $150 \mu \mathrm{l}$ of kuchala tubers tincture and to the control group $150 \mu \mathrm{l}$ normal water perorally throughout 30 days. After that, we observed the behavior of animals through the window in the next room and have taken note of the changes in the behavior of animals.

\section{Blood collection}

Blood samples were collected from each guinea pig two times, five days before the starting and after finishing the giving tincture of the tuber, under isoflurane (3-5\%) anesthesia. Blood was collected from the cranial vena cava according to previously well described method [22]. During the phlebotomy, the rules of asepsis and antiseptics were strictly observed [13]. Blood from a cranial vena cava was obtained using 25-gauge, 5/8-in needle attached to $3 \mathrm{ml}$ syringe (Zhejiang Huafu Medical Equp. Co. LTD China). Collected blood immediately transferred into Gel/Clot Activator (GD060SGC) tubes for serum collection and EDTA.K3 (GD060EK3) tubes for general blood analysis. In addition, blood smears have been done for cytology.

\section{Blood analysis}

Blood was stored for up to 2-3 hours before processing in a refrigerator at $4{ }^{\circ} \mathrm{C}$. Then we submitted blood samples to the human clinical-diagnostic laboratory for processing and analysis. The hematological analysis was carried out by using an APUIA 560 Hematology System (Siemens, Germany) for 1-2 minute, serum biochemistry was analyzed by using Beckman Coulter AU 480 (USA-Japan) for 15-20 minute and immune chemiluminescence tests were analyzed by using ImmuLite 2000 XPi (Immunoassay system) (Siemens, Germany) for 1 hour 6 minute. These machines calibrated routinely every 6 months by service professionals using a commercial. An Erythrocyte Sedimentation Rate (ESR) has been done manually. Blood smears were stained with MGG Quick Stain (04-090805, Bio Optica Milano s.p.a.) in flooded slide preparation.

\section{Necropsy}

The anesthetized animals were euthanized by exsanguination and were necropsied according to standard procedure [23]. The heart, liver and testes were extracted and their gross anatomy data (color, consistency, blood filling) were studied. Liver and testes morphometric parameters were recorded (length, width, thickness) and weight of organs (electronic weight scale Precisa, Switzerland).

\section{Histology}

Tissue samples from the testis and liver for the microscopic study were fixed in neutral buffered $4 \%$ formaldehyde ( $\mathrm{pH}$ 7.4) overnight at room temperature. After standardized histological processing to paraffin, sections (4 $\mu \mathrm{m}$ thick) were cut with automated Leica RM2255 rotary microtome and followed by staining with hematoxylin and eosin. A Nikon ECLIPSE 50i microscope equipped with a Nikon Digital Sight DS-Fi1 camera was used for observation and photography.

\section{Statictical analysis}

The obtained hematological and serum biochemical data were subjected to statistical processing. Mean, SDs, Median, Student's t-test, Min and Max values were calculated with software (Microsoft Excel). A value of $P<0.05$ was considered as statistically significant. 


\section{Results}

\section{Physical characteristics of tubers and tincture}

Dried kuchala tubers are discoid (Fig. 2a) in the main, 2-6 cm across, 2-2.3 cm thick. The color of the peel was light brown and hard. When cleaning of the peel, it flaked off into small and hard scales. Under the hard peel of the tuber was a soft, thin, and easily removed shell of a yellowish-white color. On transverse sections, the tuber was yellowwhite color (Fig. 2b), easily cut and was soft consistency as plasticine. Tubers were pressed easily and formed a mushy oily mass. The kuchala tubers were not a pungent smell. The taste was not immediately felt, but a few times later, a strong bitter taste was felt as spicy pepper, which was lasted for a long time. The prepared $10 \%$ tincture of tubers on $70 \%$ ethanol was transparent and viscous, yellowish-reddish in color (Fig. 2c). The tincture has a special bitter smell, different from the smell of alcohol.

\section{Animal behavior}

The behavior of animals in both groups was observed from the next room through a window and the results of observation were recorded. Control and experimental groups, led an active lifestyle, often ran and played, fought among themselves, ate well. However, gradually, day after day, an increase in the appetite and activity of experimental animals was observed when compared to the control group. Experimental animals often fought among themselves and were more aggressive. Sometimes they climbed on the sidewalls of the isolator cage.

\section{Hematology}

We observed no adverse effects considering clinical signs of anemia and other disorders, after guinea pigs were phlebotomized under isoflurane anesthesia.

Common hematology parameters as WBC, neutrophils, lymphocytes, monocytes, eosinophils, basophils, RBC, Hgb, $\mathrm{Hct}, \mathrm{MCV}, \mathrm{MCH}, \mathrm{MCHC}$, color indicator, erythrocyte sedimentation rate, platelets and mean platelet volume were evaluated (Table 1). The results of the study showed that several parameters of the blood were significantly different between control and experimental groups (Fig. 3). Neutrophils's percentage in experimental animals was significantly lower $\left({ }^{\mathrm{d} P}<0.001\right)$ than in control animals. Lymphocyte counts on the contrary were significantly higher in experimental animals ( $\left.{ }^{\mathrm{d}}<0.001\right)$. RBC counts, $\mathrm{Hgb}, \mathrm{Hct}, \mathrm{MCH}$ and $\mathrm{MCHC}$ were significantly higher in

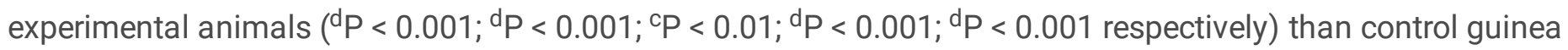
pigs. However, the color indicator and mean platelet volume on the contrary were higher $\left({ }^{\mathrm{b}} \mathrm{P}<0.05\right)$ and significantly higher $\left({ }^{\mathrm{d}} \mathrm{P}<0.001\right)$ respectively in control animals than experimental animals. Other hematological parameters as WBC, monocytes, eosinophils, basophils, MCV, erythrocyte sedimentation rate, platelets between animal groups were not statistically significant.

\section{Note}

the hematological and serum biochemistry parameters of the animals obtained before the experiment and the animals in control group almost no difference. Therefore, only the parameters of control group animals were shown.

\section{Serum biochemistry}


In this study, some serum biochemical parameters such as ALT (alanine aminotransferase), AST (alanine aminotransferase), glucose and testosterone were evaluated (Table 2). As a result, three of them (ALT, AST and testosterone) were significantly different between the control and experimental groups of animals (Fig. 4). ALT and AST percentages in experimental animals were significantly lower than control animals (both ${ }^{d} P<0.001$ ). The testosterone concentration was considerably higher $\left({ }^{d} \mathrm{P}<0.001\right)$ in experimental guinea pigs and glucose percentage in serum was not statistically significant between studied animal groups.

\section{Gross anatomy and histology}

In a comparative aspect, all internal organs were visually studied, especially the heart, liver, kidneys and testes in both control and experimental groups. Results of a visual examination of the color, consistency and degree of blood filling of the above-mentioned organs of the control and experimental groups of necropsied guinea pigs did not reveal any significant differences. Comparative morphometric studies (organ weight, width, length and thickness) of the liver and testes in animals of both groups were also not statistically significant. Therefore, we did not provided comparative morphometric data of studied organs.

Microscopic examination of the blood smears also revealed no noticeable differences or changes between animals' control and experimental groups. Only WBC of guinea pigs of the experimental group were reflected (Fig. 5) without a description of the structural features of each of them.

Microscopic examination of the control guinea pig liver had visualized normal hexagonal hepatic lobules in various sizes having hepatocytes, central vein with blood cells, sinusoids along with empty spaces and not clearly visible macrophages (Kupffer cells), lining the in different places of sinusoids (Fig. 6a). Liver sections of experimental animals were stained pale if compared to the control group. Liver cords, sinusoids, intensive stained Kupffer cells, several apoptotic figures and apoptosomes (Fig. 6a*) were clearly visible.

Histological examination of the control guinea pig testes section had shown tubular glands and intertubular connective tissue by the specific intestinal or Leydig cell. The round-oval seminiferous tubules are various sizes and they surrounded with loose vascular connective tissue by forming lobules of testis. The coiled seminiferous tubules are lined with a multilayered spermatogenic cells on different develop stages and sustentacular or Sertoli cells (Fig. 6b). There were decreased in the number of spermatogenic cells in seminiferous tubules. Experimental testis section showed restoration of spermatogenesis in seminiferous tubules (Fig. 6b*). The amount of spermatogonias, primary spermatocytes, spermatids were increased. The lumen of seminiferous tubule was filled with developing spermatozoa.

\section{Discussion}

This paper is devoted to the scientific justification of the medicinal effect of the kuchala (Arum korolkowii Regel) tuber on male potency, which has long been used in Asia folk medicine. Kyrgyz people have used a long time the tubers of this medicinal plant, adding to the process of preparing the national drink kumys (fermented milk product of mare's milk) as a means to increase the strength and endurance of males-warriors [11, 12]. Folk healers referring to the works of Avicenna are indicating, that the kuchala tubers with wine are stimulates sexual desire and detoxifies the kidneys. However, the recipe for making with kumys and wine has not written in detail and modern folk healers also it keeps in secret. Based on the above, we prepared a $10 \%$ tincture of kuchala tubers in $70 \%$ ethyl 
alcohol. The next important stage of research planning was the choice of the type of laboratory animal for experimental study. For this purpose, we analyzed the literature data and found that among different laboratory animal's guinea pig has many morphofunctional similarities with human, namely by the lung physiology [24], hormonal, immunological and corticosteroid responses $[13,14]$. Importantly, the guinea pig has many common features with human reproduction - by presenting of the accessory glands [16,17], characteristics of the placenta [25], morphological and functional analysis of spermatogenesis [26]. Besides, it has available information that the content of testosterone and androstenedione in serum and testis were different in guinea pigs in the prenatal [20, 27], and postnatal [28] periods. The concentration of testosterone in plasma reaches its maximum level at 60 days of age in guinea pigs, and then testosterone decreases with the increase of age. In the 24-35-month-old guinea pigs decreased by $65 \%$ the concentration of testosterone in blood plasma [28]. Ancient Kyrgyz people used the kumys tinctures of the tuber who has disorders of sexual libido or older men over 70 years old used strengthen the bone system and potency. In this regard especially, the adult male guinea pigs were selected \pm 48 -months of age, which their testosterone level is low. Additionally in guinea pigs have been studied in detail the structure of testicles [29], epididymis [30] and spermatogenesis [31]. The above-mentioned data served as a justification for the use of guinea pigs in this experimental study.

For the comparative analysis, we studied the hematological and serum biochemical parameters of guinea pigs. According to hematological and serum biochemical data of inbred strain, $13 / \mathrm{N}$ guinea pigs were divided into the following age groups - the juveniles (0-150 days), adults (151-900 days) and geriatric adults (older than 900 days) [32]. Our selection for the experimental study guinea pigs at the age of 48 months, although from a different breed, are fully meets to our goal for choose of old animals.

In our study in a comparative aspect, were studied sixteen hematological (Table 1) and four serum biochemistry parameters (Table 2) of blood. Based on our data, we can say with confidence that the goal of this experimental work has been achieved. Since the concentration of testosterone in the blood plasma are more than twice increased in experimental animals $(21.73 \pm 2.11 \mathrm{~d})$ compared to control animals $(9.533 \pm 0.184)$, which is confirmed statistically ( $\left.{ }^{d} \mathrm{P}<0.001\right)$. In addition, it is confirmed with microstructural changes in the testes where showed improvement of spermatogenesis, i.e. with increases of spermatogenesis cells in seminiferous tubules.

However, some hematological parameters, such as the lymphocytes, RBC, $\mathrm{Hgb}, \mathrm{Hct} \mathrm{MCH}, \mathrm{MCHC}$, color indicator and mean platelet volume were significantly increased in the experimental guinea pigs $\left({ }^{d} P<0,001 ;{ }^{d} P<0,001 ;{ }^{c} P<0.01\right.$; ${ }^{d} P<0,001 ;{ }^{d} P<0,001 ;{ }^{d} P<0,001,{ }^{b} P<0.05,{ }^{d} P<0,001$ respectively), than control animals. On the contrary, neutrophils' percentage in experimental animals was significantly lower ( $\left.{ }^{d} P<0,001\right)$ than in control animals. Such suspicious data indicates the toxic effect of tincture on the organism of guinea pigs. This is probably due to the dose $(0.15 \mu \mathrm{l})$ or high concentration of the tuber tincture $(10 \%)$, possibly with higher diluted solution of ethanol (70\%), or a long time of giving the tincture (30 consecutive days) to guinea pigs. Hepatocellular injures can be evaluated using serum biochemistry parameters of alkaline phosphatase (ALP) and alkaline aminotransferanse (ALT) [13]. The toxic effect of this tincture on the organism of guinea pigs also confirmed with a decrease in the concentration of ALT and AST in plasma biochemistry in experimental guinea pigs, which were statistically significant ( $\left.{ }^{\mathrm{P}} \mathrm{P}<0.001\right)$. Lowering ALT and AST indicates that severe liver damage occurs, and it associated with a sharp reduction in active liver cells. Such a process observed in cirrhosis or necrosis of the liver. The toxic effects of any drugs or toxic substances in the organism are expressed by the damages to the structure of liver [33, 34]. Gross anatomy parameters of the liver of both animal groups were similar, which is consistent with the data of other researchers of the liver of guinea pigs [35]. However, microscopic examination revealed some differences in the liver 
in experimental animals. The liver sections of the experimental animal pale-stained and all microstructural components liver - cords, sinusoids, Kupffer cells were clearly visible. There were several apoptotic figures and apoptosomes in the liver parenchyma. As known, pale staining of cell structures indicated low functional activity of the organ. Moreover, the microstructure of the liver of the control group completely coincides with the data of other researchers [36] were not detected pathohistological changes.

\section{Conclusion}

The present study shows the $10 \%$ kuchala (Arum korolkowii Regel) tuber tincture in $70 \%$ ethanol has a positive effect to improve the sexual potency of old male guinea pigs by increasing the production of testosterone and increasing the spermatogenesis. The toxic effects of this tincture to the animal organism can be resolved by reducing the dose. The concentration of the drug, tincture in ethanol will be the main aim of our next study.

\section{Declarations}

\section{Acknowledgements}

We thank Dr. Zarima Jumakanova, Peil Esengul kyzy and Ella Abylaevafor support technical editing and proofreading.

\section{Authors' contributions}

AN and JJ conceived, designed and realized the study. JJ, ON, KB and SK were participated in the experimental work. AN, TA and SR took blood and necropsied animals. KG and TA provided academic instruction. AN, TA, KG, BB and ShG conducted data collection and analysis. ChK made statistical processing of the data. AN interpreted and wrote the draft manuscript. All authors read and approved the final manuscript.

\section{Funding}

This work was not funded.

\section{Availability of data and materials}

All data generated or analyzed during this study are included in this published article.

\section{Ethics approval and consent to participate}

Animal Experiments Local Ethics Committee at the Kyrgyz-Turkish Manas University (Kyrgyz Republic) approved the current experimental study (№7, 20/12/2019).

\section{Consent for publication}

Not applicable.

\section{Competing interest}

The authors declare that they have no conflict of interests.

\section{Author details}


${ }^{1}$ Department of Biology, Faculty of Sciences, Kyrgyzstan-Turkey Manas University, Bishkek 720042, Kyrgyz Republic;

${ }^{2}$ Department of Chemical Engineering, Faculty of Engineering, Kyrgyzstan-Turkey Manas University, Bishkek 720042, Kyrgyz Republic;

${ }^{3}$ Department of Basic Sciences, Faculty of Veterinary medicine, Kyrgyzstan-Turkey Manas University, Bishkek 720042, Kyrgyz Republic.

\section{References}

1. Suleman S. et al. Treatment of malaria and related symptoms using traditional herbal medicine in Ethiopia. Ethnopharmacol. 2018;213:262-279. https://doi.org/10.1016/j.jep.2017.10.034.

2. Soelberg J. and Jäger A.K. Comparative ethnobotany of the Wakhi agropastoralist and the Kyrgyz nomads of Afghanistan. Ethnobiol. Ethnomed. 2016;12(1):1-24. https://doi.org/10.1186/s13002-015-0063-x.

3. Miara M.D., Bendif H., Hammou M.A. and Teixidor-Toneu I. Ethnobotanical survey of medicinal plants used by nomadic peoples in the Algerian steppe. Ethnopharmacol. 2018;219:248-256.

https://doi.org/10.1016/j.jep.2018.03.011.

4. Sõukand R. and Pieroni A. The importance of a border: Medical, veterinary, and wild food ethnobotany of the Hutsuls living on the Romanian and Ukrainian sides of Bukovina. Ethnopharmacol. 2016;185:17-40. https://doi.org/10.1016/j.jep.2016.03.009.

5. Tulobaev A.Z. Range of Medicinal Plants Used in Folk Veterinary Medicine in Kyrgyzstan. Manas J. Agric. Vet. Life Sci. 2019;9(2):91-98. Available: https://dergipark.org.tr/tr/pub/mjavl/issue/51057/638745.

6. Wang Guo-Qiang, Huang Lu-Qi, Xie Dong-Mei. [Introduction of traditional medicinal plants in Kyrgyzstan]. Zhongguo Zhong Yao Za Zhi, 2014;39(3):391-396. Available: https://pubmed.ncbi.nlm.nih.gov/24946536/.

7. Eisenman S.W., Zaurov D.E. and Struwe L. Medicinal plants of Central Asia: Uzbekistan and Kyrgyzstan. Springer; 2013. Available: https://link.springer.com/book/10.1007/978-1-4614-3912-7.

8. Haigh A. et al. Arum korolkowii Regel. Plants of the World online, 2011. Available: http://powo.science.kew.org/taxon/urn:Isid:ipni.org:names:86049-1.

9. Guo R. et al. Botany, Phytochemistry, Pharmacology and Toxicity of Strychnos nux-vomica L.: A Review. J. Chin. Med. 2018;46(1):1-23. https://doi.org/10.1142/S0192415X18500015.

10. Patel K., Laloo D., Singh G.K., Gadewar M. and Patel D.K. A review on medicinal uses, analytical techniques and pharmacological activities of Strychnos nux-vomica Linn.: A concise report. J. Integr. Med. 2017;221005:1-13. https://doi.org/10.1007/s11655-016-2514-1.

11. Orozbakov S. Manas IV; 1997. Available: https://new.bizdin.kg/kniga/manas-eposu-4-kitep.

12. Mamai J. Semetey Zhusup Mamais variant; 2017. Available: http://erkindik.net/forum/topic/690-семетейжусуп-мамайдын-айтымында/.

13. Williams W.R., Jonston M.S., Higgins S., Izzo A.A., Kendall L.V. Blood profiles in unanesthetized and anesthetized Guinea pigs (Cavia porcellus). Lab Anim. (NY). 2016;45(1):35-41.

https://doi.org/10.1038/laban.911.

14. Padilla-Carlin D.J., McMurray D.N. and Hickey A.J. The guinea pig as a model of infectious diseases. Med. 2008;58(4):324-340. Available: https://pubmed.ncbi.nlm.nih.gov/18724774/. 
15. Suzuki O., Koura M., Noguchi Y., Takano K., Yamamoto Y. and Matsuda J. Optimization of superovulation induction by human menopausal gonadotropin in guinea pigs based on follicular waves and FSH-receptor homologies. Reprod. Dev. 2003;64(2):219-225. https://doi.org/10.1002/mrd.10242.

16. Gradela A. et al. Morphologic and morphometric description of the guinea pigs vesicular gland during postnatal development. Vet. Bras. 2013;33(7). https://doi.org/10.1590/S0100-736X2013000700017.

17. Gradela A. et al. Morphological and morphometric study of the prostate of guinea pigs (Cavia porcellus, Linnaeus, 1758) during postnatal development. Biotemas, 2013;26(4):221-231. https://doi.org/10.5007/21757925.2013v26n4p221.

18. Rodríguez-Casuriaga R., Geisinger A., Santiñaque F.F., López-Carro B. and Folle G.A. High-purity flow sorting of early meiocytes based on DNA analysis of guinea pig spermatogenic cells. Part A, 2011;79A(8):625-634. https://doi.org/10.1002/cyto.a.21067.

19. Rodríguez Rosana E., Wettstein Rodolfo M. Quantitative Study on Guinea Pig Spermatogenesis Shows a Relative High Percentage of Early Meiotic Prophase Stages. Rec. - Part A Discov. Mol. Cell. Evol. Biol. 2004;278(1):493-504. https://doi.org/10.1002/ar.a.20037.

20. Nunes A.K.R. et al. Morphological development of the testicles and spermatogenesis in Guinea pigs (Cavia porcellus Linnaeus, 1758). Morphol. Sci. 2017;34(3):143-151. https://doi.org/10.4322/jms.107816.

21. Acosta S., Dizeyi N., Feinstein R., Pierzynowski S., Abrahamsson P-A. Long-term testosterone stimulation induces hyperplasia in the guinea-pig prostate. Prostate Cancer Prostatic Dis. 2004;7(3):227-231. https://doi.org/10.1038/sj.pcan.4500744.

22. Williams W.R. and Kendall L.V. Blood collection in the guinea pig (Cavia porcellus). Lab Anim. (NY). 2015;44(6):207-208. https://doi.org/10.1038/laban.787.

23. Kopteva K.E. et al. The technique of autopsy and removal of organs in laboratory animals. Anim. Sci. Res. 2019;2. https://doi.org/10.29296/2618723X-2019-02-05.

24. Noonan D.E. The Guinea Pig (Cavia porcellus). Genet. 1975; September 1994:275-307. Available: https://www.researchgate.net/publication/235936317_The_Guinea_Pig_Cavia_porcellus.

25. Card S.E., Brien J.F. No effect of chronic ethanol administration of the activity of alcohol dehydrogenase and aldehyde dehydrogenases in the near-term pregnant guinea pig. J. Physiol. Pharmacol. 1989;67(6):601-606. https://doi.org/10.1139/y89-096.

26. Nunes AKR et al. Morphological and functional analysis of spermatogenesis in guinea pigs (Cavia porcellus) from pre-puberty to post-puberty. Vet. Bras. 2013;33:1-7. Available:

https://paperity.org/p/186129324/morphological-and-functional-analysis-of-spermatogenesis-in-guinea-pigscavia-porcellus.

27. Pelardy G. and Delost P. Secretion of the androgens in the male guinea-pig during the perinatal period. Acta Endocrinol. (Copenh). 1978;89(4):770-779. https://doi.org/10.1530/acta.0.0890770.

28. Rigaudiere N., Pelardy G., Robert A. and Delost P. Changes in the concentrations of testosterone and androstenedione in the plasma and testis of the guinea pig from birth to death. Reprod. Fertil. 1976;48(2):291300. https://doi.org/10.1530/jrf.0.0480291.

29. Simões L.S. et al. The quantification of testicular cells during the postnatal development in two Caviomorph rodents: The guinea pig (Cavia porcellus) and the cutia (Dasyprocta agouti). Acad. Bras. Cienc. 2017;89(3):1745-1751. https://doi.org/10.1590/0001-3765201720170038. 
30. Uppal V., Bansal N., Pathak D. and Kumar A. Histomorphochemical studies on the epididymis of guinea pig. Indian J. Anim. Sci. 2009;79(8):809-812. Available:

https://www.researchgate.net/publication/271647135_Histomorphochemical_studies_on_testis_of_guinea_pig.

31. Simões L.S. et al. Ultrastructural analysis of the spermatogenesis in the guinea pig (Cavia porcellus). Vet. Bras. 2016;36:89-94. https://doi.org/10.1590/S0100-736X2016001300013.

32. Genzer S.C., Huynh T., Coleman-McCray J.A.D., Harmon J.R., Welch S.R. and Spengler J.R. Hematology and clinical chemistry reference intervals for inbred strain 13/N Guinea pigs (Cavia porcellus). Am. Assoc. Lab. Anim. Sci. 2019;58(3):293-303. https://doi.org/10.30802/AALAS-JAALAS-18-000118.

33. Fan Y., Liu S., Chen X., Feng M., Song F. and Gao X. Toxicological effects of Nux Vomica in rats urine and serum by means of clinical chemistry, histopathology and 1H NMR-based metabonomics approach. Ethnopharmacol. 2018;210:242-253. https://doi.org/10.1016/j.jep.2017.06.027.

34. Uche F., Obianime A. and Gogo-Abite M. Effects of Vanadium Pentoxide on the Histological and Sperm Parameters of Male Guinea Pigs. Appl. Sci. Environ. Manag. 2010;12(3).

https://doi.org/10.4314/jasem.v12i3.55512.

35. Stan F.G. Comparative Study of the Liver Anatomy in the Rat, Rabbit, Guinea Pig and Chinchilla. Univ. Agric. Sci. Vet. Med. Cluj-Napoca. Vet. Med. 2018;75(1):33. https://doi.org/10.15835/buasvmcn-vm:002717.

36. Rosas C.C., Vásquez B.P. and del Sol M. Histological and Histochemical description of the liver of the guinea pig (Cavia porcellus). Int. J. Morphol. 2010;28(1):151-156. https://doi.org/10.4067/S071795022010000100021.

\section{Tables}

Due to technical limitations, table 1 and 2 is only available as a download in the Supplemental Files section.

\section{Figures}




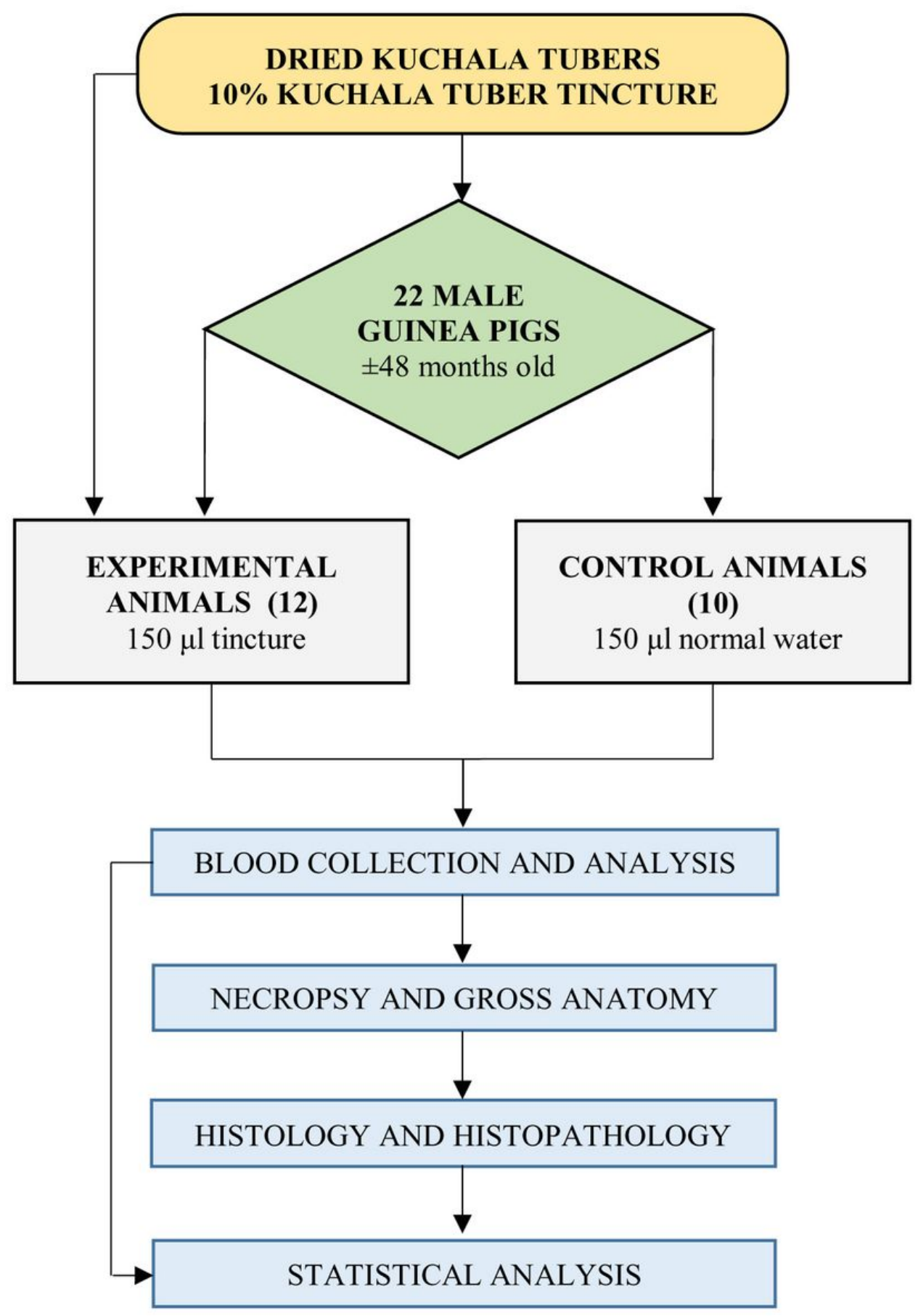

Figure 1

The main phases of the experimental study. 


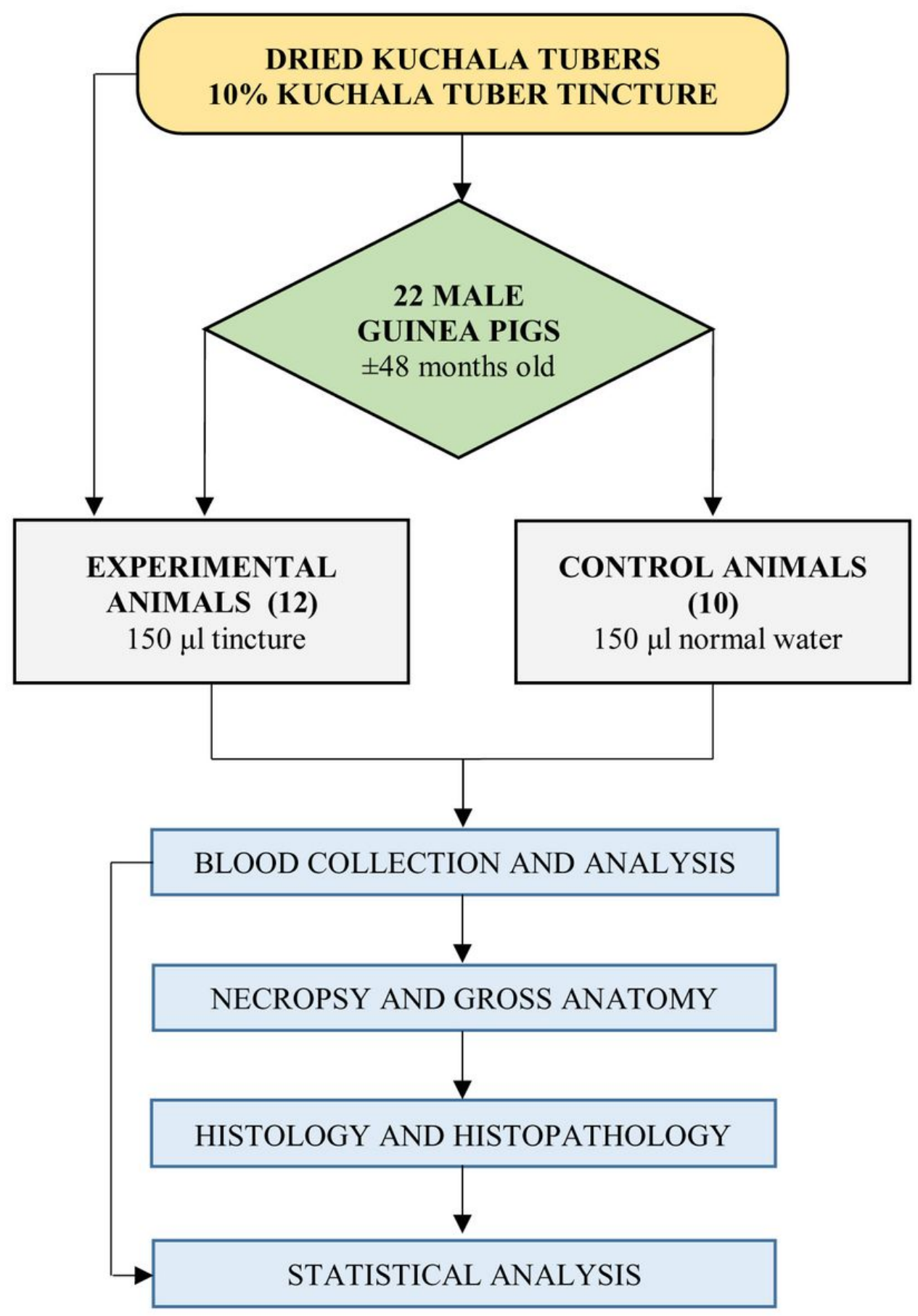

Figure 1

The main phases of the experimental study. 


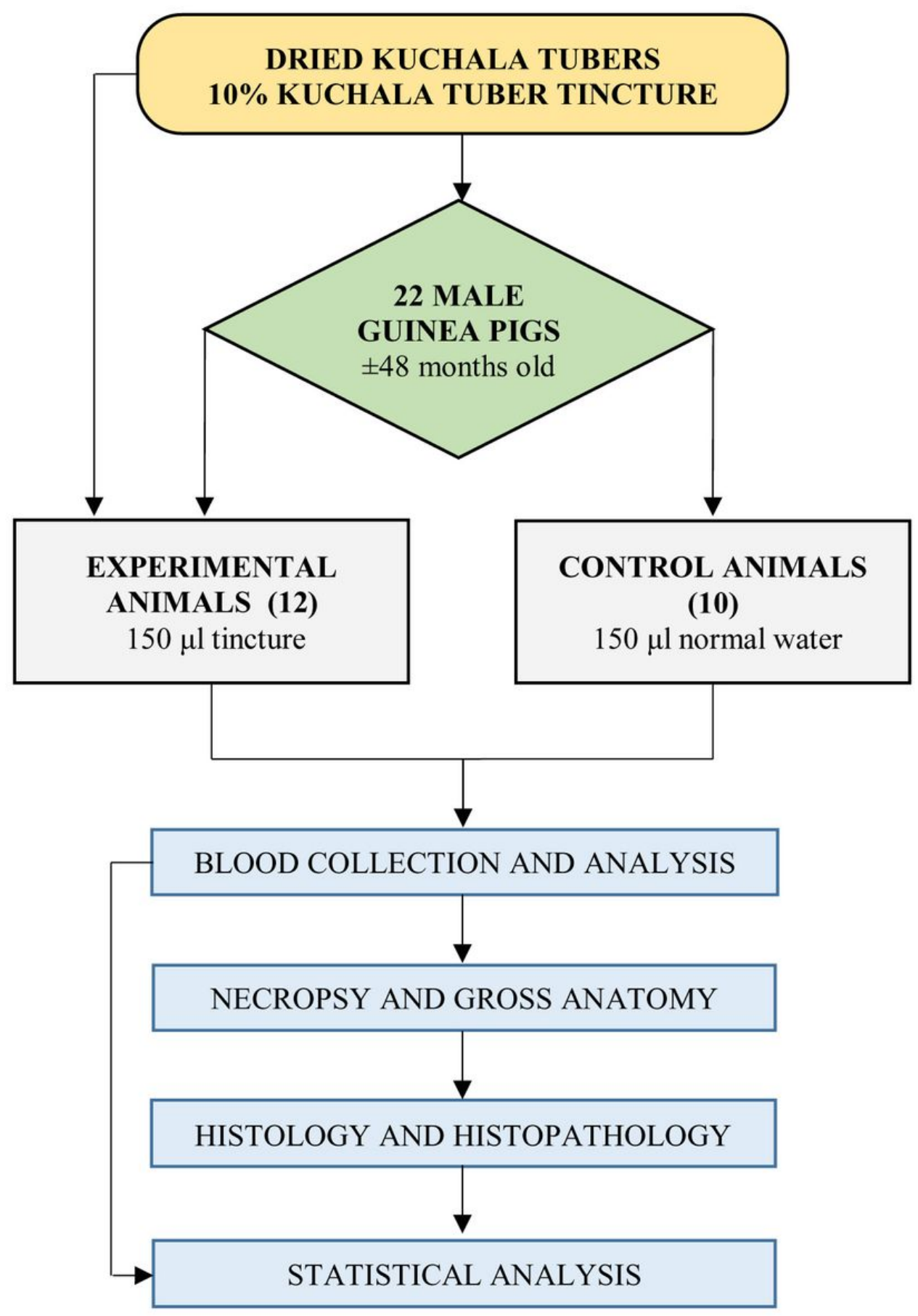

Figure 1

The main phases of the experimental study. 

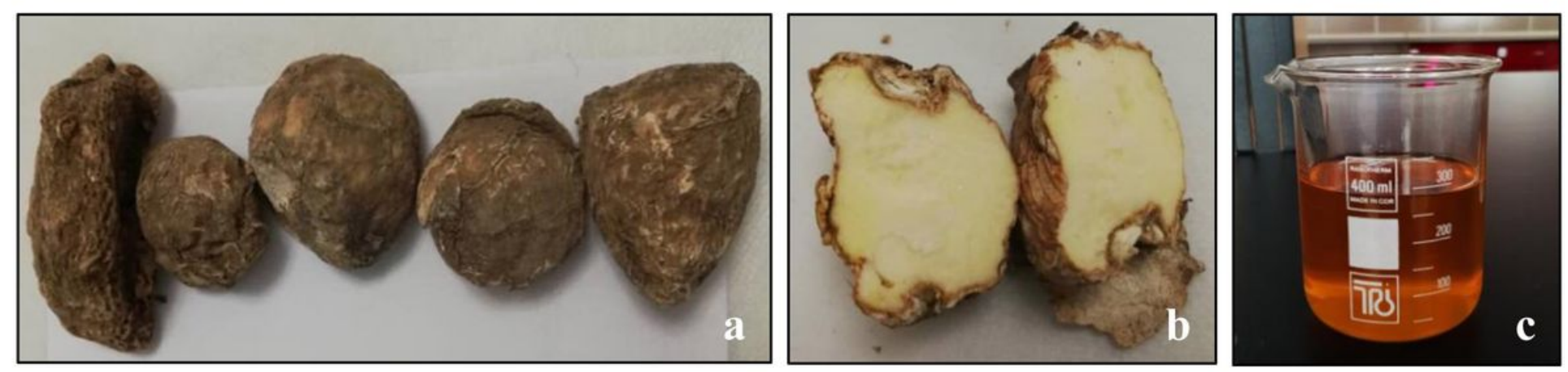

\section{Figure 2}

View of the outside (a) and on transvers sections (b) dried kuchala (Arum korolkowii Regel) tubers and prepared $10 \%$ tincture (c).
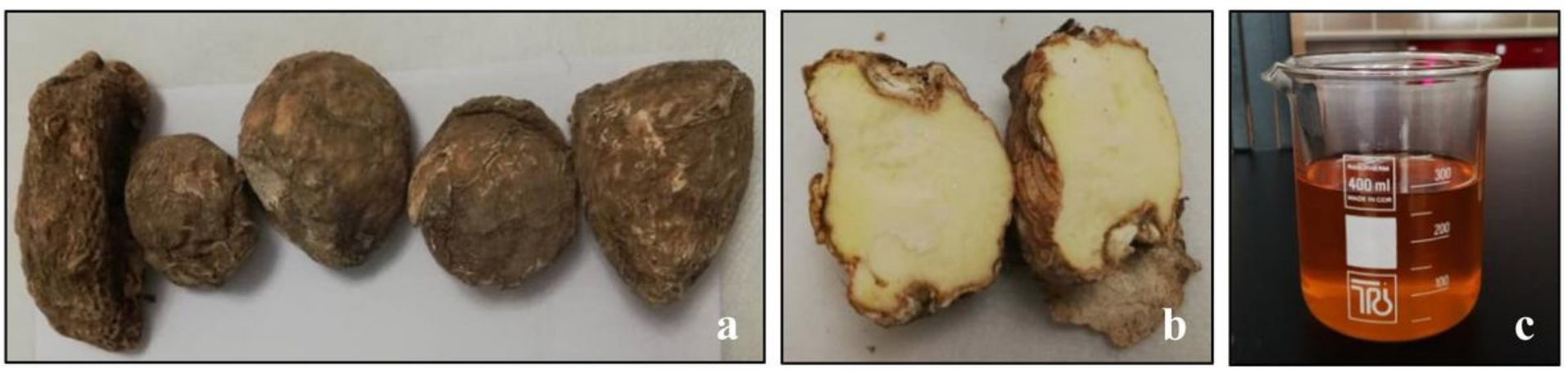

\section{Figure 2}

View of the outside (a) and on transvers sections (b) dried kuchala (Arum korolkowii Regel) tubers and prepared $10 \%$ tincture $(\mathrm{c})$.
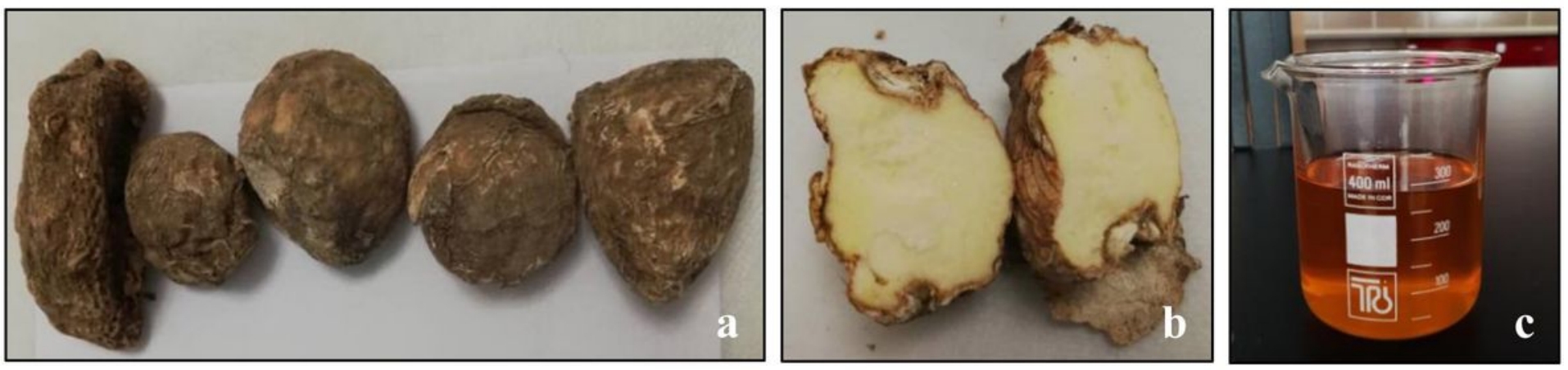

\section{Figure 2}

View of the outside (a) and on transvers sections (b) dried kuchala (Arum korolkowii Regel) tubers and prepared $10 \%$ tincture (c). 


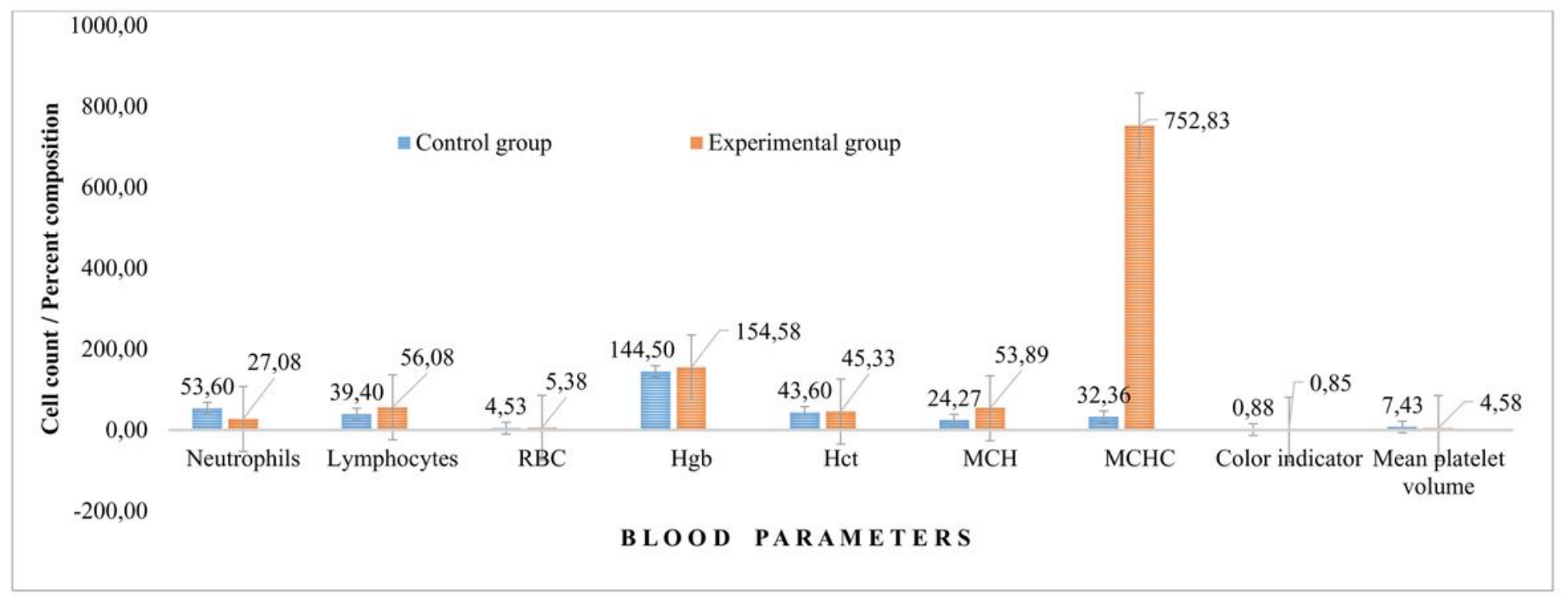

\section{Figure 3}

Hematological parameters (mean \pm s.e.m.) which were significantly different between the control and experimental groups of guinea pigs. Notable differences were observed in percentage of neutrophils $(\mathrm{dP}<0.001)$, lymphocytes $(d P<0.001), R B C(d P<0.001), H g b(d P<0.001)$, Hct (cP < 0.01), MCH (dP < 0.001), MCHC $(d P<0.001), H c t(b P<$ $0.05)$ and mean platelet volume $(\mathrm{dP}<0.001)$.

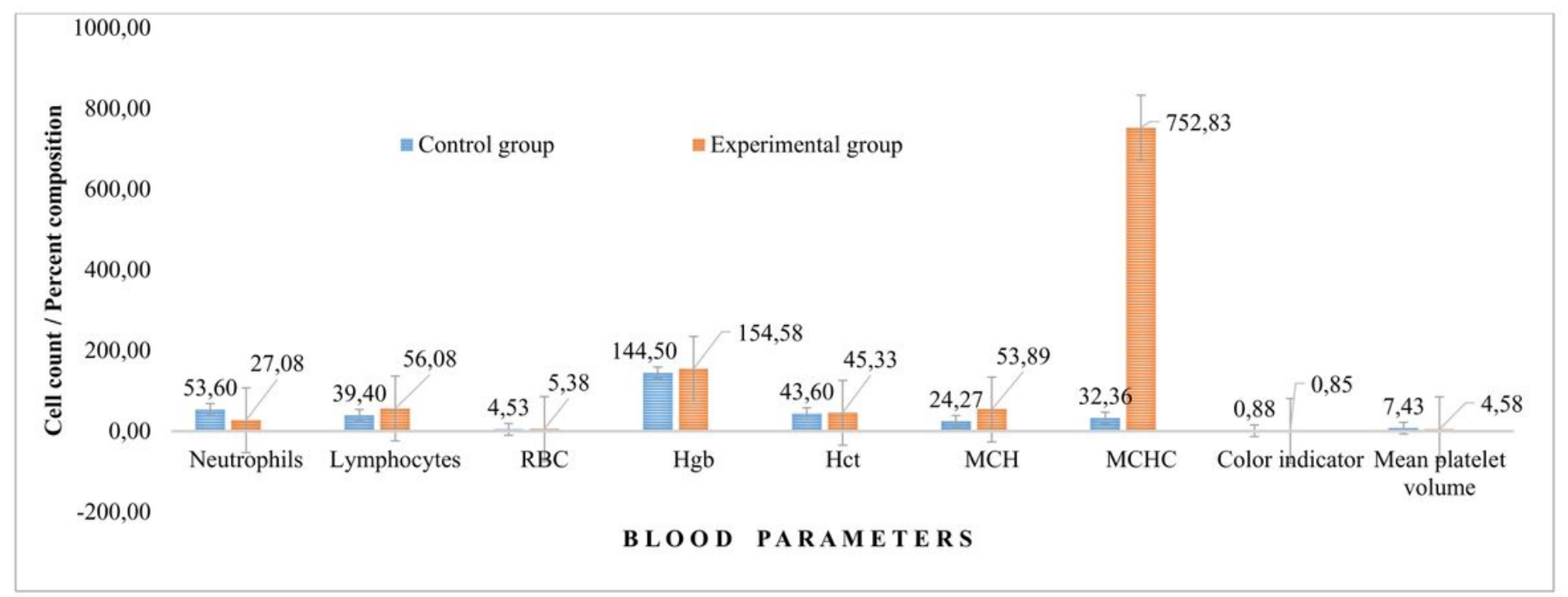

\section{Figure 3}

Hematological parameters (mean \pm s.e.m.) which were significantly different between the control and experimental groups of guinea pigs. Notable differences were observed in percentage of neutrophils $(\mathrm{dP}<0.001)$, lymphocytes $(\mathrm{dP}<0.001)$, RBC (dP < 0.001), Hgb (dP < 0.001), Hct (cP < 0.01), MCH $(\mathrm{dP}<0.001), \mathrm{MCHC}(\mathrm{dP}<0.001), \mathrm{Hct}(\mathrm{bP}<$ $0.05)$ and mean platelet volume $(\mathrm{dP}<0.001)$. 


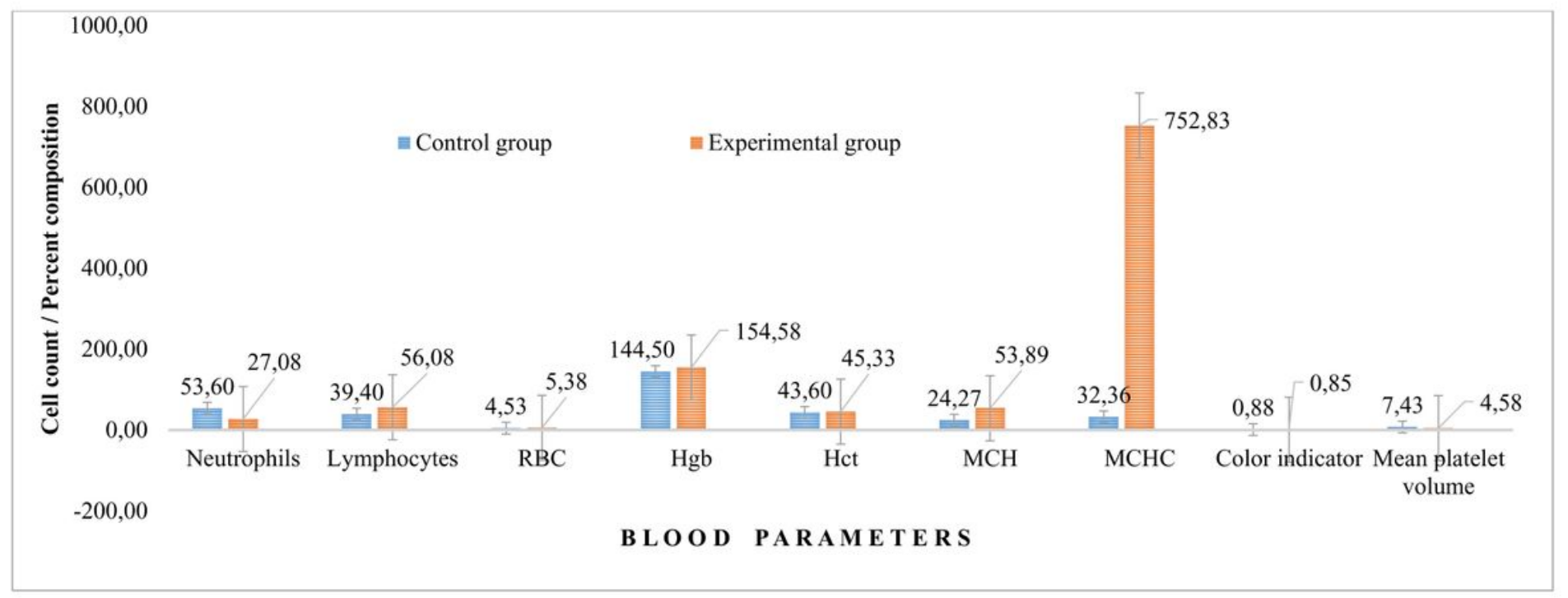

\section{Figure 3}

Hematological parameters (mean \pm s.e.m.) which were significantly different between the control and experimental groups of guinea pigs. Notable differences were observed in percentage of neutrophils $(\mathrm{dP}<0.001)$, lymphocytes $(d P<0.001), R B C(d P<0.001), H g b(d P<0.001)$, Hct (cP < 0.01), MCH (dP < 0.001), MCHC $(d P<0.001), H c t(b P<$ $0.05)$ and mean platelet volume $(\mathrm{dP}<0.001)$.

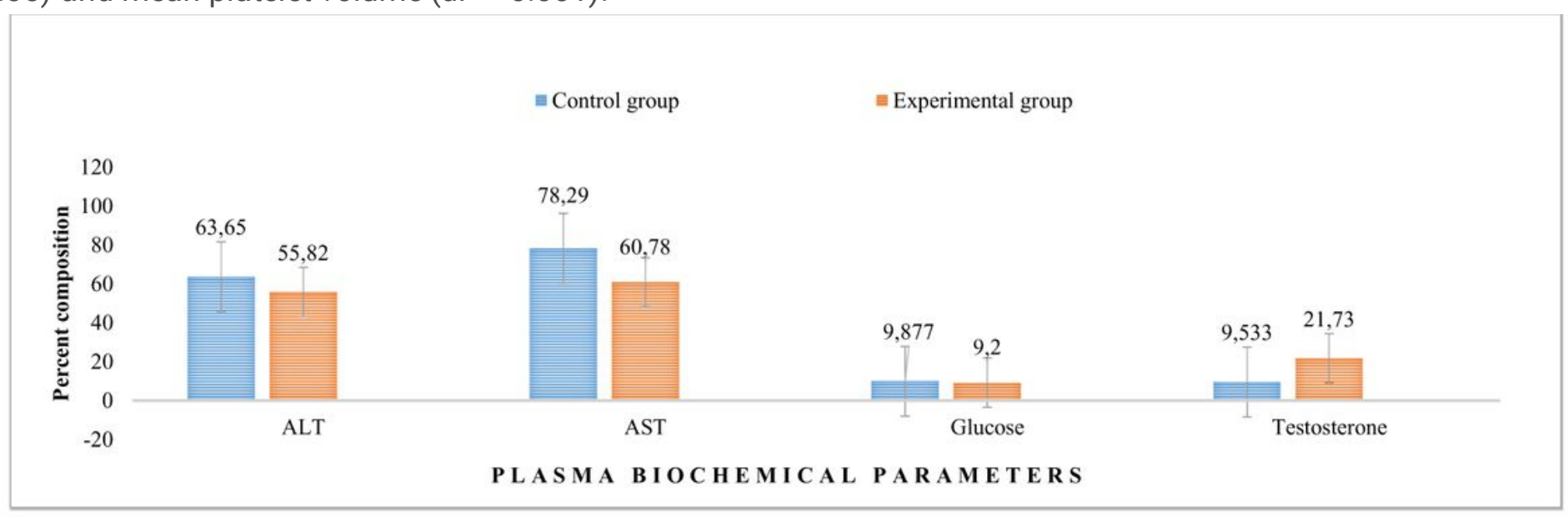

\section{Figure 4}

Serum biochemistry parameters (mean \pm s.e.m.) of guinea pigs in control and experimental groups. Besides percentage of glucose in serum, notable differences were observed in percentage of ALT $(d P<0.001), A S T$ (dP $<$ $0.001)$ and testosterone $(\mathrm{dP}<0.001)$. 


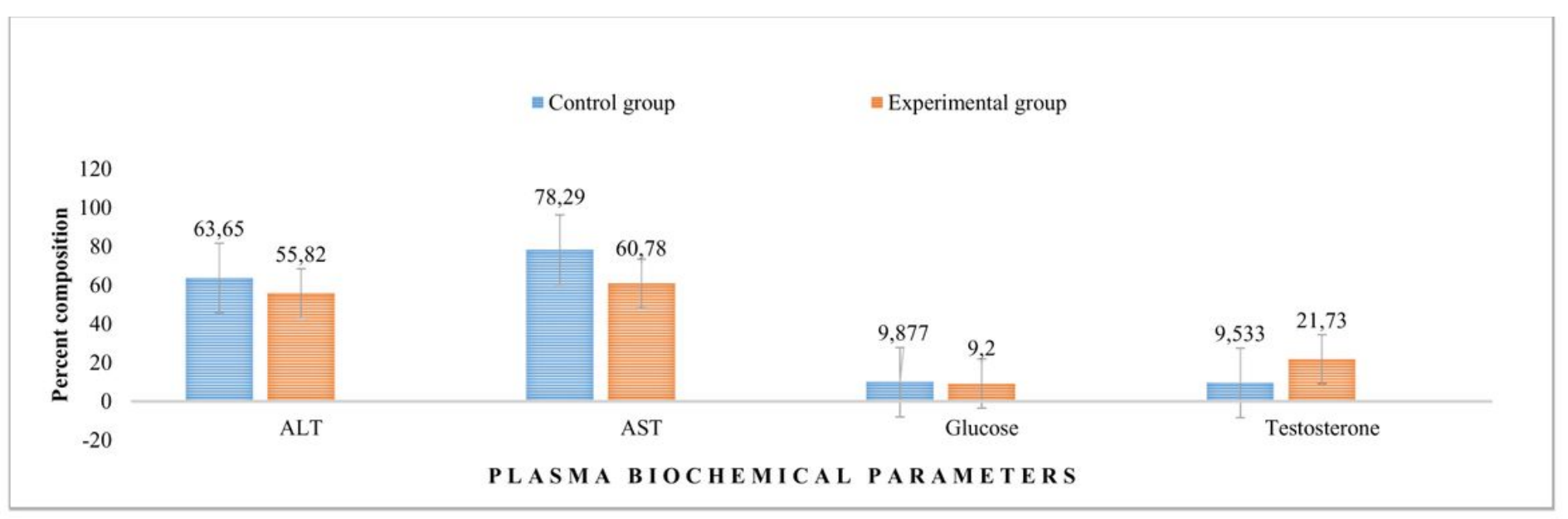

\section{Figure 4}

Serum biochemistry parameters (mean \pm s.e.m.) of guinea pigs in control and experimental groups. Besides percentage of glucose in serum, notable differences were observed in percentage of $A L T(d P<0.001)$, AST (dP < $0.001)$ and testosterone $(\mathrm{dP}<0.001)$.

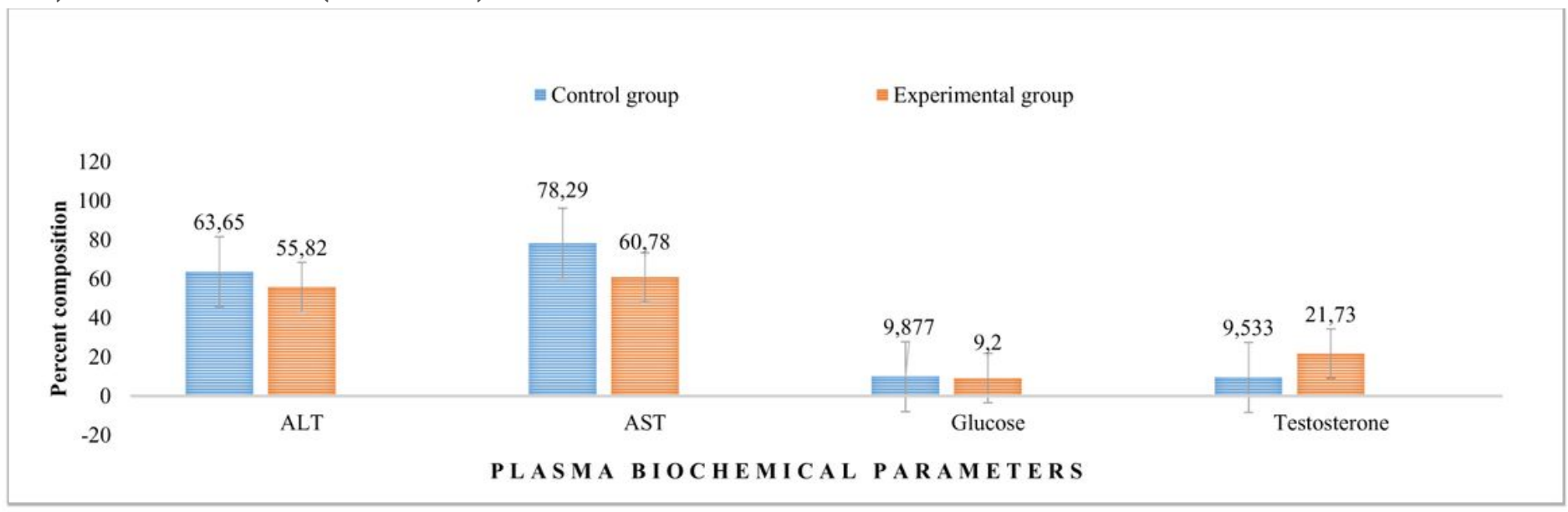

\section{Figure 4}

Serum biochemistry parameters (mean \pm s.e.m.) of guinea pigs in control and experimental groups. Besides percentage of glucose in serum, notable differences were observed in percentage of $A L T(d P<0.001), A S T(d P<$ $0.001)$ and testosterone $(\mathrm{dP}<0.001)$. 

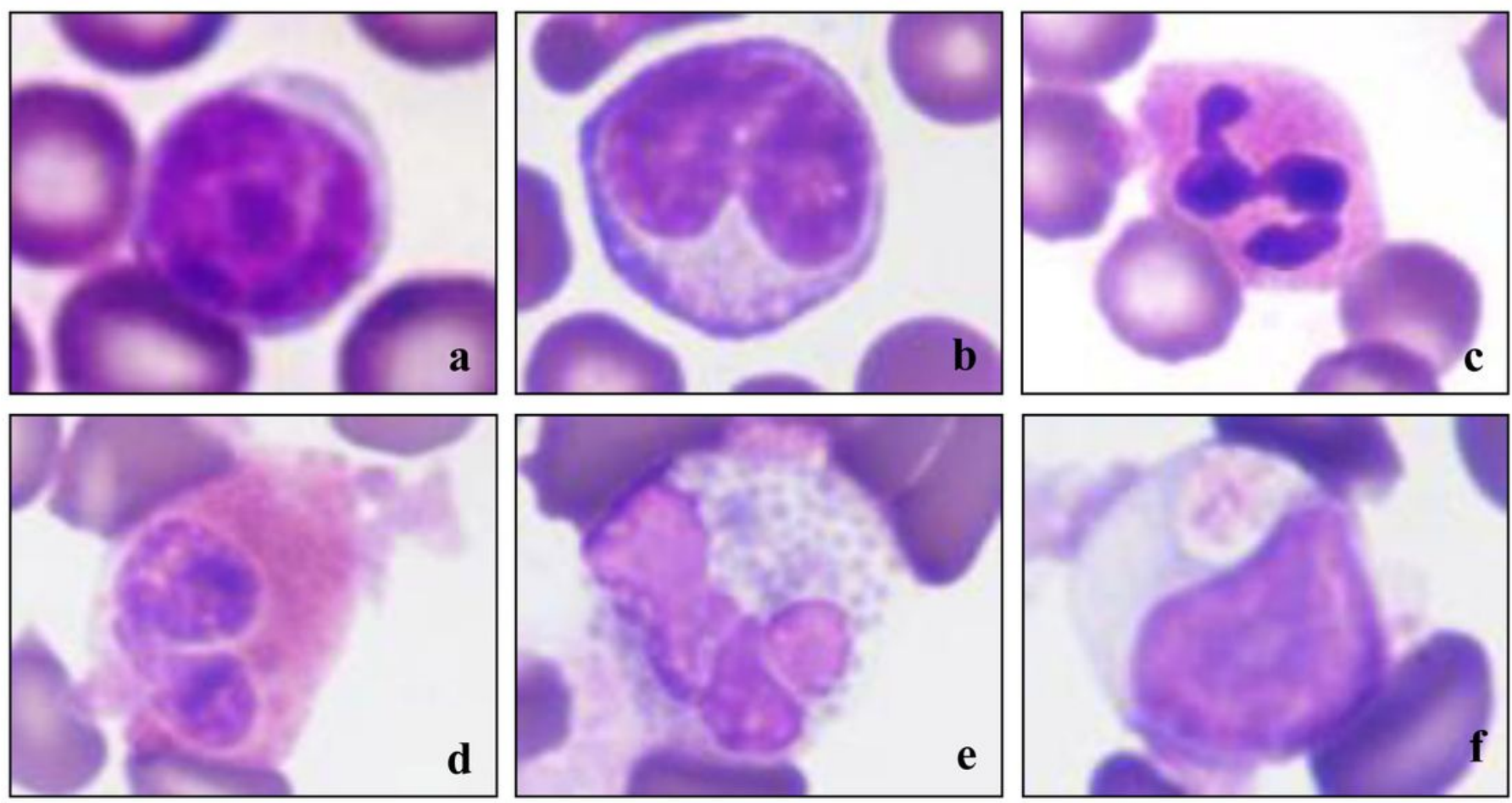

\section{Figure 5}

WBC are commonly found in guinea pig blood smears. Lymphocyte with biggest nucleus and small cytoplasmic rim (a), bean-shaped nuclear monocyte (b), segmented neutrophil (c) and eosinophil with purple-colored granules in the cytoplasm (d), basophil with characteristic blue-purple granules (e) and Foa-Kurloff cell with pink intracytoplasmic inclusion body (f). MGG Quick Stain staining, x100 (oil immersion).
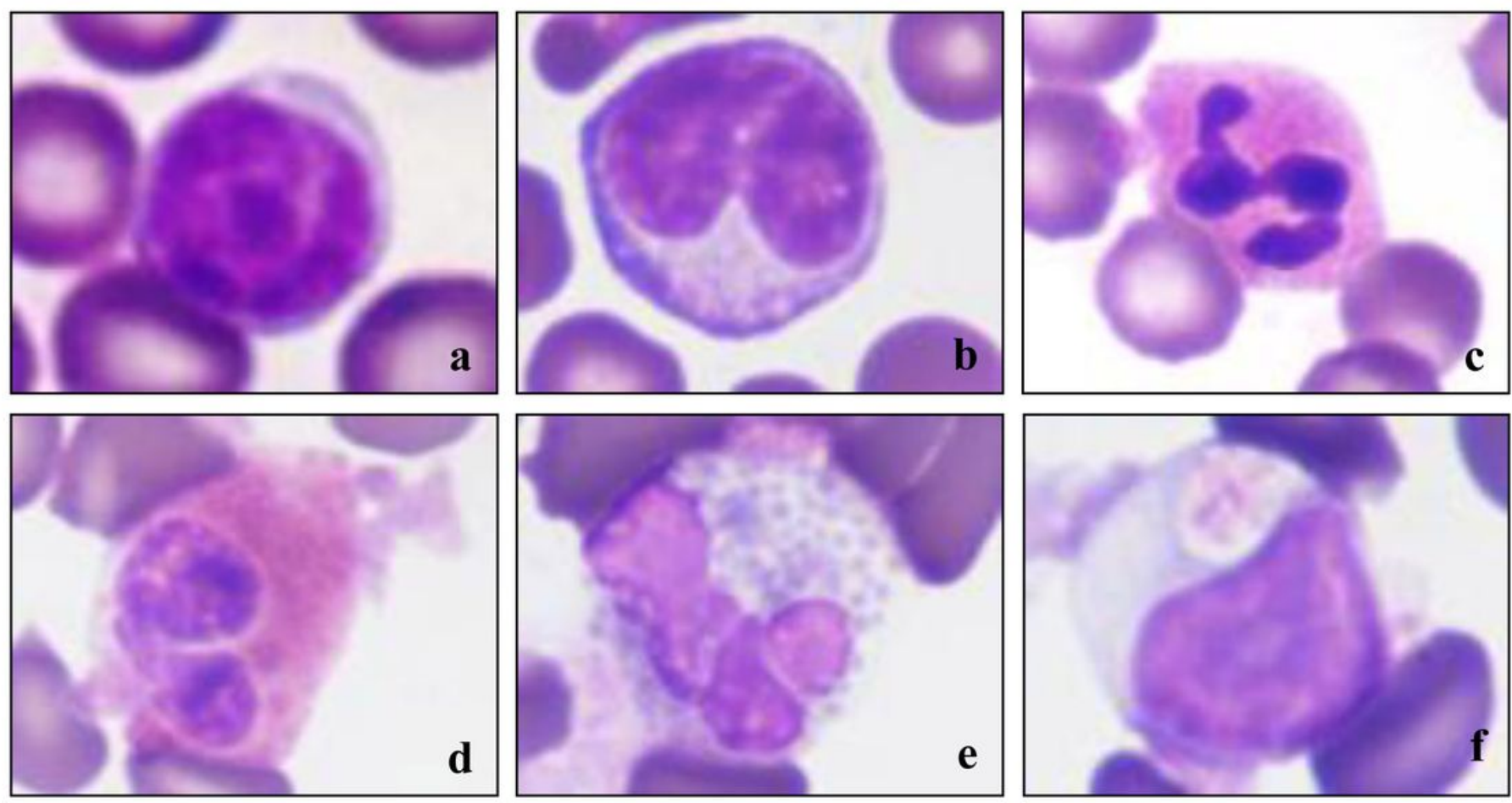

Figure 5 
WBC are commonly found in guinea pig blood smears. Lymphocyte with biggest nucleus and small cytoplasmic rim (a), bean-shaped nuclear monocyte (b), segmented neutrophil (c) and eosinophil with purple-colored granules in the cytoplasm (d), basophil with characteristic blue-purple granules (e) and Foa-Kurloff cell with pink intracytoplasmic inclusion body (f). MGG Quick Stain staining, x100 (oil immersion).
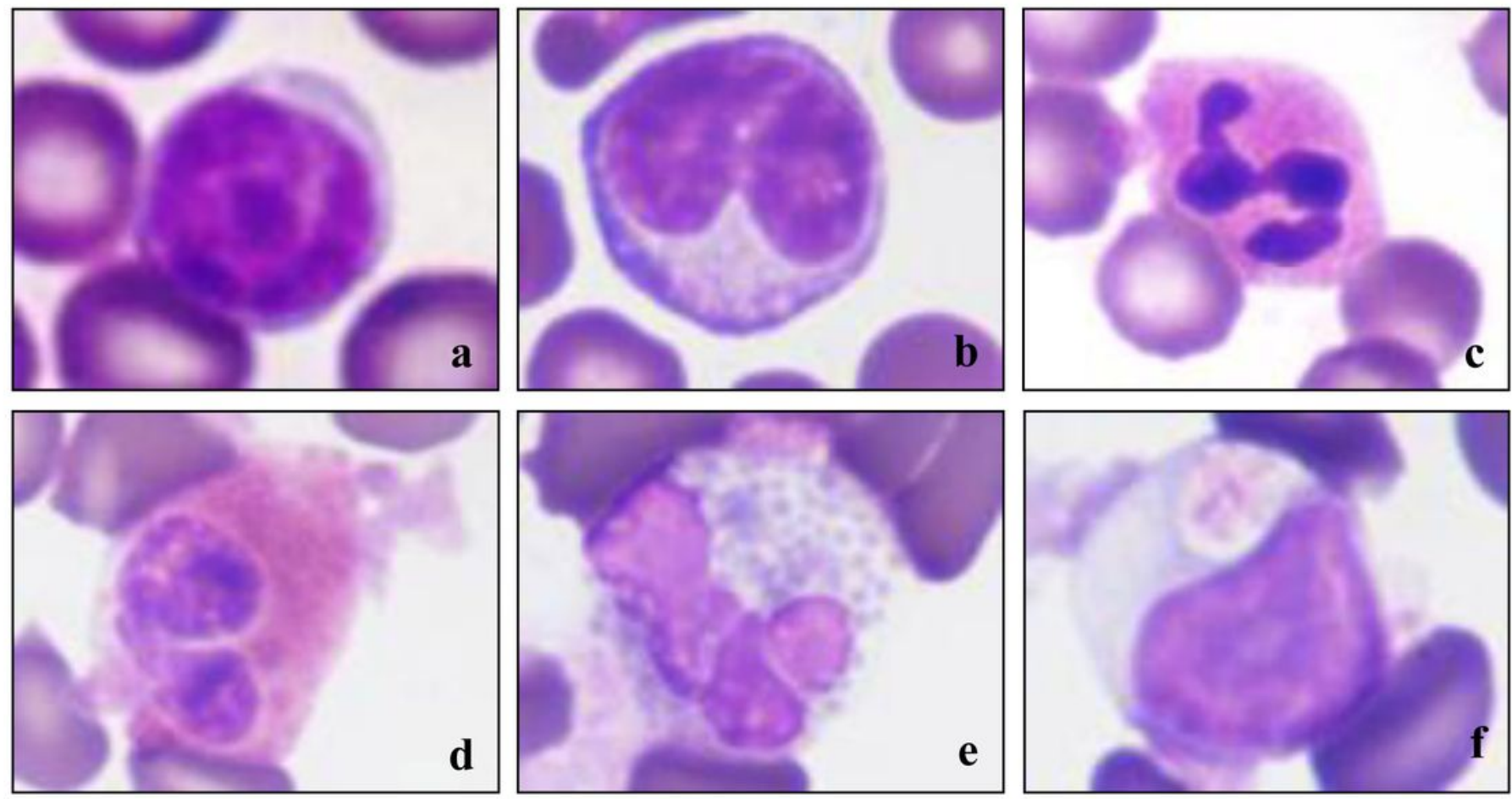

\section{Figure 5}

WBC are commonly found in guinea pig blood smears. Lymphocyte with biggest nucleus and small cytoplasmic rim (a), bean-shaped nuclear monocyte (b), segmented neutrophil (c) and eosinophil with purple-colored granules in the cytoplasm (d), basophil with characteristic blue-purple granules (e) and Foa-Kurloff cell with pink intracytoplasmic inclusion body (f). MGG Quick Stain staining, x100 (oil immersion). 

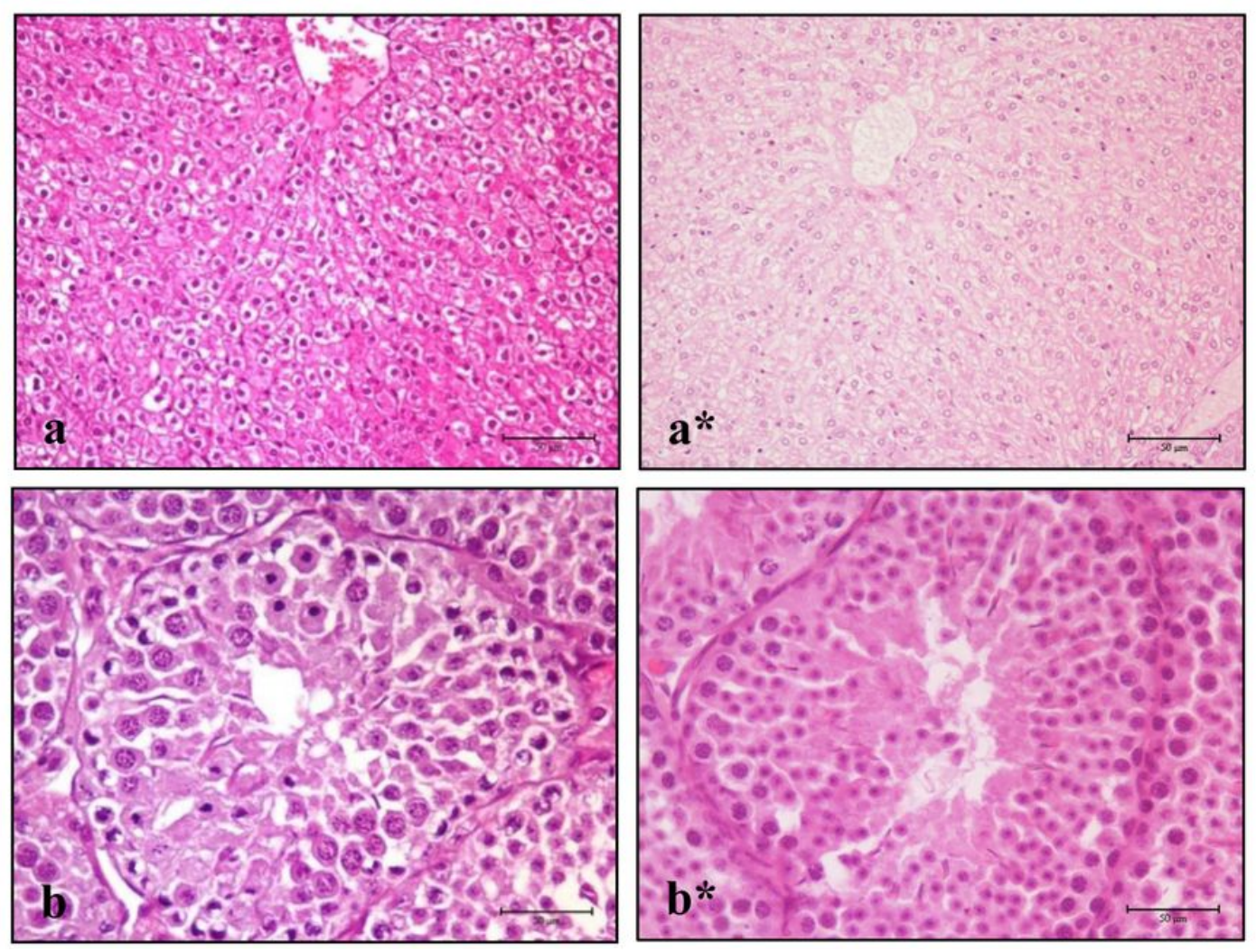

\section{Figure 6}

Photomicrographs of paraffin sections of control (a) and experimental (a*) liver and control (b) and experimental $\left(b^{\star}\right)$ testis of guinea pigs. Intensive stained normal hepatic lobule with hepatocytes, sinusoids, some macrophages (a) and pale stained experimental hepatic lobule with clearly visible sinusoids, some intensive stained Kupffer cells, apoptotic figures $\left(a^{*}\right)$. Control testis section showed the round-oval seminiferous tubule with multilayered spermatogenic cells and sustentacular cells (b). Experimental testis section showed same picture ( $\left.b^{\star}\right)$, but there is an increase spermatogenic cells. Hematoxylin and eosin staining, x20 (a, a*) and x40 (b, b*). 

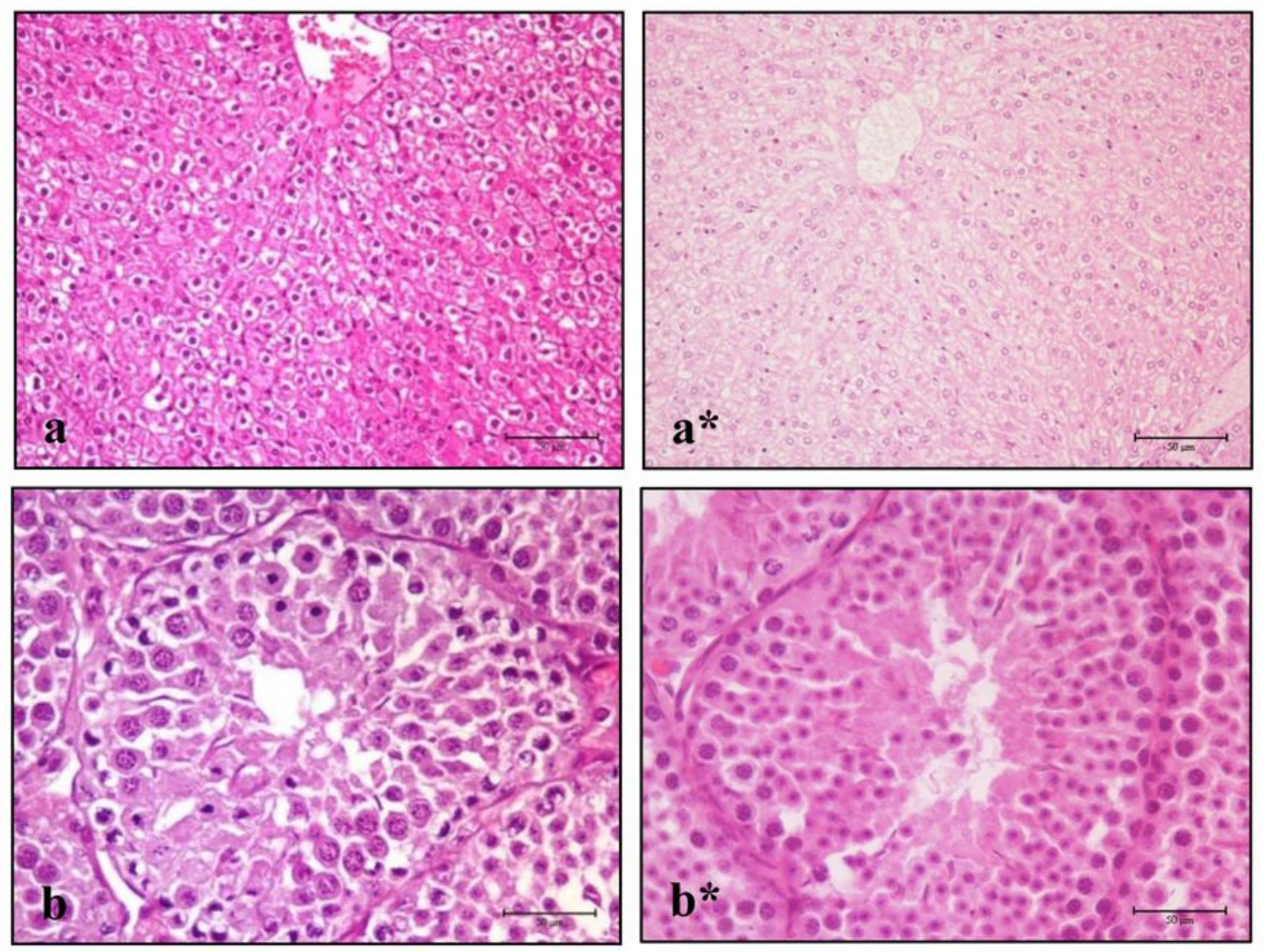

\section{Figure 6}

Photomicrographs of paraffin sections of control (a) and experimental (a*) liver and control (b) and experimental $\left(b^{\star}\right)$ testis of guinea pigs. Intensive stained normal hepatic lobule with hepatocytes, sinusoids, some macrophages (a) and pale stained experimental hepatic lobule with clearly visible sinusoids, some intensive stained Kupffer cells, apoptotic figures $\left(a^{*}\right)$. Control testis section showed the round-oval seminiferous tubule with multilayered spermatogenic cells and sustentacular cells (b). Experimental testis section showed same picture ( $\left.b^{\star}\right)$, but there is an increase spermatogenic cells. Hematoxylin and eosin staining, x20 (a, a*) and x40 (b, b*). 

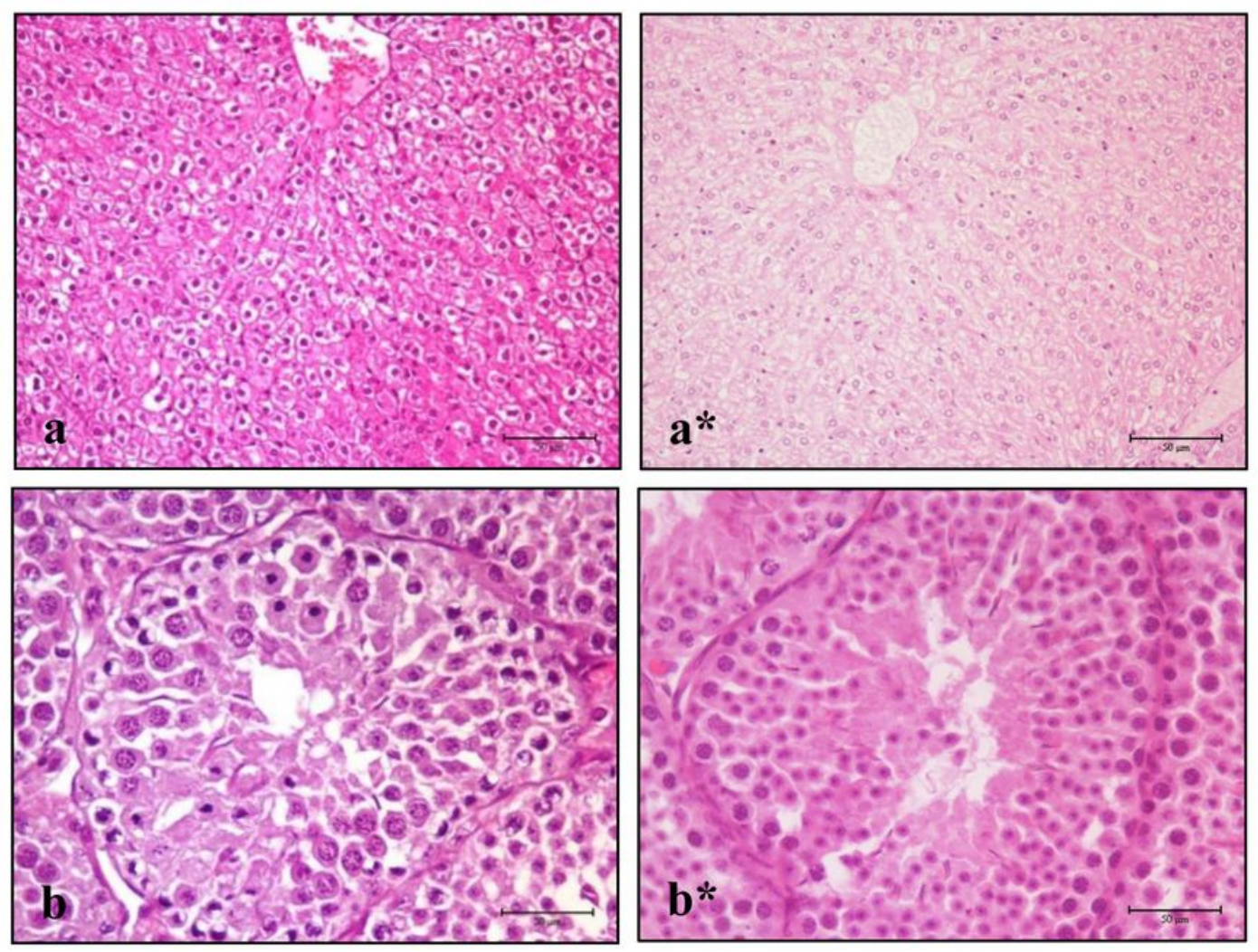

\section{Figure 6}

Photomicrographs of paraffin sections of control (a) and experimental (a*) liver and control (b) and experimental $\left(b^{\star}\right)$ testis of guinea pigs. Intensive stained normal hepatic lobule with hepatocytes, sinusoids, some macrophages (a) and pale stained experimental hepatic lobule with clearly visible sinusoids, some intensive stained Kupffer cells, apoptotic figures $\left(a^{*}\right)$. Control testis section showed the round-oval seminiferous tubule with multilayered spermatogenic cells and sustentacular cells (b). Experimental testis section showed same picture ( $\left.b^{\star}\right)$, but there is an increase spermatogenic cells. Hematoxylin and eosin staining, $x 20\left(a, a^{*}\right)$ and x40 (b, b*).

\section{Supplementary Files}

This is a list of supplementary files associated with this preprint. Click to download.

- Table1.pdf

- Table1.pdf

- Table1.pdf

- Table2.pdf

- Table2.pdf

- Table2.pdf 